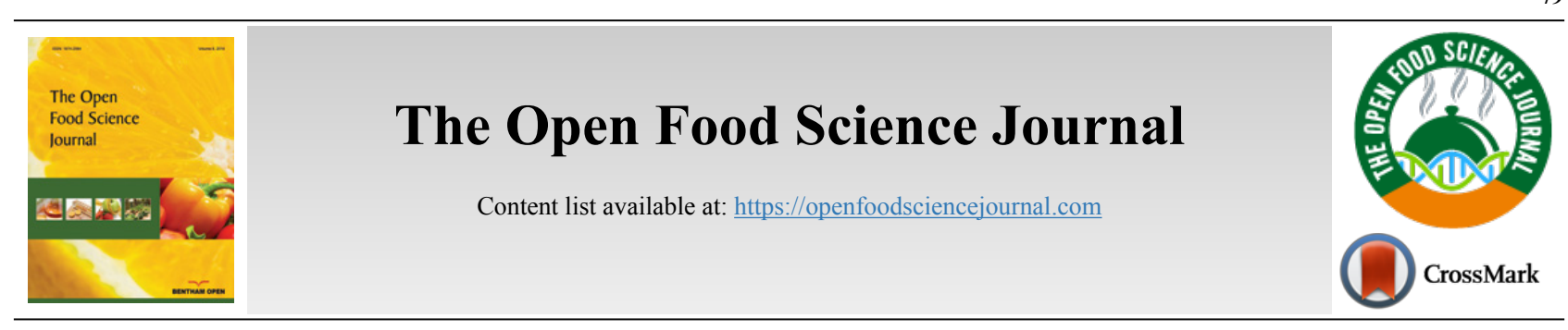

RESEARCH ARTICLE

\title{
Lipid Class and Fatty Acid Compositions of Dried Sea Cucumber Apostichopus japonicus
}

Md Anisuzzaman ${ }^{1}$, Feng Jin ${ }^{1}$, Kamrunnahar Kabery ${ }^{1}$, U-Cheol Jeong ${ }^{1}$, Hyun-Chol Jung ${ }^{2}$, Sang-Ro Lee ${ }^{2}$ and Seok-Joong $\mathrm{Kang}^{1, *}$

${ }^{\prime}$ Department of Marine Biology and Aquaculture, Gyeongsang National University, Tongyeong 53064, South Korea ${ }^{2}$ A1 Engineering Co., Ltd, Suncheon, 540856, South Korea

\begin{abstract}
:
Introduction:

Sea cucumber, Apostichopus japonicus, is becoming popular around the world due to its nutritional and medicinal properties. There are still no detailed chemical studies of the lipid class, glycolipids compositions of sea cucumber.

Methods:

This study was conducted to determine the lipid class and glycolipid compositions of dried sea cucumber, A. japonicus, and analyze fatty acid compositions of Monogalactosyl Diglycerides (MGDG), Steryl Glycosides (SG) and Sulfoquinovosyl Diglycerides (SQDG). Total lipids of sea cucumber were extracted by Bligh and Dyer method and Sep-Pak Silica plus long cartridge, and Thin Layer Chromatography (TLC) silica gel G-60 F254 was used for the separation of different lipid classes and glycolipid compositions. The composition of fatty acids was analyzed by GC.

Results \& Conclusion:

The level of total lipids in the dried sea cucumber, Apostichopus japonicus, was $4 \pm 1 \%$ of dry weight $(\mathrm{w} / \mathrm{w})$ and the amount of neutral lipids, glycolipids and phospholipids was $31 \pm 1 \%, 29 \pm 1 \%$ and $40 \pm 1 \%$ of the total lipids (w/w), respectively. MGDG, SG and SQDG were the major glycolipids, and the contents were $37.5 \pm 0.3 \%, 33.8 \pm 0.5 \%$ and $23.6 \pm 0.7 \%$ of the total glycolipids $(\mathrm{w} / \mathrm{w})$, respectively and significantly higher than other glycolipids $(p<0.05)$. SQDG contained much higher Arachidonic Acid (AA), Eicosapentaenoic Acid (EPA) and MGDG contained higher Docosahexaenoic Acid (DHA) compared with SG $(p<0.05)$. Further investigation is required to understand the positional distribution of fatty acids and molecular species in MGDG, SG and SQDG in detail.
\end{abstract}

Keywords: Sea cucumber, Lipid class, Total lipids, Glycolipids, Fatty acids, Echinoderms, Aquaculture.

Article History

Received: April 23, 2019

Revised: May 30, 2019

Accepted: June 20, 2019

\section{INTRODUCTION}

Sea cucumbers belong to the phylum Echinodermata, class Holothuroidea. There are about 1,200 holothurian species in the world and commonly known as trepang, bêche-de-mer, or gamat [1]. Among echinoderms, sea cucumber Apostichopus japonicus is becoming popular around the world and the market demand of this species is increasing rapidly because of its dietary, aphrodisiac and curative properties [2]. Natural production of sea cucumbers has decreased due to overexploitation and pollution [3]. Depletion of natural production together with high commercial value has

\footnotetext{
"Address correspondence to this author at the Seok-Joong Kang, Department of Marine Biology and Aquaculture, Gyeongsang National University, Tongyeong 53064, South Korea; Tel: +82. 55. 772. 9154; Fax: +82. 55. 648. 3089; E-mail: sjkang54@gmail.com
}

encouraged the people to develop aquaculture methods for sea cucumber culture [3 - 5]. However, worldwide production of sea cucumber has increased rapidly through aquaculture. China is the world leading country in sea cucumber production. Under controlled conditions, sea cucumbers are intensively mass-produced in Recirculating Aquaculture Systems (RAS) [6]. Moreover, sea cucumbers are very suitable species for coculture or integrated multi-trophic aquaculture because they feed on organically rich substrates [6].

Sea cucumbers preferentially inhabit on muddy and sandy grounds, especially on the ocean and seashores and consume the sea bottom sediment containing organic matter, including protozoa, bacteria, diatoms, and detritus of plants or animals [7 - 12]. 
Since sea cucumbers can autolyze after they have been caught, they must be stored using various processing methods. They are usually processed into boiled, dried or salted products $[13,14]$. Sea cucumbers are usually marketed as fresh, frozen, dried, cooked-dried, cooked-salted and cooked-salted-dried products $[15,16]$. Ferdouse [17] reported that sea cucumbers are mainly exported in dried form, but a small quantity of fresh and frozen sea cucumbers has also entered the international business. Approximately, $90 \%$ of this business takes place in the Asian Far East such as China, Hong Kong, Malaysia and Singapore [17].

Sea cucumbers have many therapeutic effects with high protein and low lipid content and contain minerals and vitamins such as magnesium, iron, calcium, zinc, vitamin A, riboflavin, niacin and thiamine [18 - 25]. Sea cucumber extracts have many bioactive compounds and have antiviral, anticancer, antibacterial, antioxidant, anti-inflammation effe-cts [26 - 30]. Lipids of sea cucumber play essential roles in the metabolic activities of organisms' effects [31,32]. Long-chain polyunsaturated fatty acids Especially Eicosapentaenoic Acid (EPA) and Docosahexaenoic Acid (DHA) may reduce the risk of coronary heart disease, cancer, inflammation and arthritis $[33,34]$ and arachidonic acid is responsible for wound healing and blood clotting [35]. Moreover, interest in the research on sea cucumber, A. japonicus is now more intense and many researchers in this field have studied the collagen, saponin and various other aspects [36 - 38]. However, there are still no detailed chemical studies of the lipid class, glycolipid components and fatty acid compositions of MGDG, SG and SQDG. Therefore, this study was carried out to determine the the lipid class, glycolipid compositions of dried sea cucumber, A. japonicus and analyze fatty acid compositions of MGDG, SG and SQDG.

\section{MATERIALS AND METHODS}

\subsection{Experimental Sample}

Live specimens of sea cucumbers, Apostichopus japonicus were hand-picked by scuba diving. They were collected from the coast of Tongyeong, the Republic of Korea. All samples were kept in plastic bags.

\subsection{Pretreatment}

Sea cucumbers were transported to laboratory in seawater. The body of each sea cucumber was cut from the anus nearly to the oral organ and then their visceral organs were removed. The body walls were washed carefully with distilled water. The sea cucumbers were boiled at $100^{\circ} \mathrm{C}$ for $45 \mathrm{~min}$ in $3.5 \%$ saltcontaining water $[18,39]$. After that, for drying, A. japonicus samples were placed on a dry plate of a heat pump-hybrid dryer (DHPD250, A1 Engineering Co., Ltd., Korea) at $55 \pm$ $1{ }^{\circ} \mathrm{C}$ where the internal vacuum was $-2,000 \mathrm{mmAqG}$. The samples were dehydrated to a moisture content of $12 \%$ or less.

\subsection{Reagents and Instrumentation}

All reagents and solvents were of analytical grade and supplied by Sigma (Gillingham, UK) and Merck (Darmstadt, Germany). Chromatographic material used for thin layer chromatography (TLC) was silica gel G-60 F254 (Merck). The reference phospholipid standards such as acyl monogalactosyl diglycerides (Acyl MGDG), 6-0-acyl steryl glycosides (6-0acyl SG), monogalactosyl diglycerides (MGDG), steryl glycosides (SG), digalactosyl diglycerides (DGDG) and sulfoquinovosyl diglycerides (SQDG) were used.

\subsection{Total Lipid Extraction and Lipid Class Separation}

Total lipids of sea cucumber were extracted according to the Bligh and Dyer method (1959) [40] by using a solvent mixture consisting of chloroform and methanol $(2: 1, \mathrm{v} / \mathrm{v})$. After phase equilibration, the lower chloroform layer was removed and total lipids were extracted by removing the solvent using a rotary evaporator (R-114, BUCHI, Swiss) at $38^{\circ} \mathrm{C}$.

Sep-Pak Silica plus long cartridge (Waters, USA) was used for the separation of different lipid classes such as Neutral lipid (NL), Glycolipid (GL) and Phospholipid (PL) from the total lipids of sea cucumber.

Eighty milligrams of extracted total lipid was put into the cartridge and $15 \mathrm{~mL}$ of chloroform was passed through the cartridge. Then chloroform was collected and placed in a round flask, dried with a rotary evaporator, and quantified to obtain neutral lipids. After obtaining neutral lipids, $15 \mathrm{~mL}$ of acetone was eluted by passing through the cartridge, and dried in the same manner as before, and quantified to obtain glycolipids [41]. Then, $30 \mathrm{~mL}$ of methanol was eluted through the cartridge, dried with a rotary evaporator, and quantified to get phospholipids. The above procedure was repeated several times to obtain samples necessary for analysis.

\subsection{Analysis of Glycolipids}

One hundred milligrams of glycolipids was dissolved in 1 $\mathrm{mL}$ of chloroform to adjust the sample concentration. The TLC plates $(20 \times 20 \mathrm{~mm})$ coated with silica gel G-60 were activated in a dry oven at $105^{\circ} \mathrm{C}$ for $60 \mathrm{~min}$ and then cooled in a desiccator. The prepared samples were applied to the TLC plates. An elution system consisting of chloroform: acetone: water 30:60:2 $(v / v / v)$, was utilized for the separation of glycolipids. The developed TLC plates were passed through $\mathrm{N}_{2}$ to dry the TLC plates and then subjected to qualitative and quantitative analysis using a TLC scanner (CAMAG, TLC Scanner 4) [42].

\subsection{Analysis of Fatty Acid Compositions}

Methyl esters of the fatty acids contained in the MGDG, SG and SQDG were prepared as follows: $100 \mathrm{mg}$ of lipid was put into a capped tube and $1.5 \mathrm{ml} 0.5 \mathrm{~N} \mathrm{NaOH}$-methanol solution was added. The sample was mixed by vortex and heated at $100^{\circ} \mathrm{C}$ for 8 minutes for saponification. After cooling, methylation was done by using a fatty acid methyl ester (FAME) with $\mathrm{BF}_{3}$-methanol. Then the sample was dissolved to $2 \mathrm{ml}$ iso-octane and fatty acids were analyzed via GC technique using gas chromatography (Clarus 600, Perkin Elmer, USA) equipped with a capillary column (Omegawax-320, $30 \mathrm{~m} \times$ $0.25 \mathrm{~mm}$ I.D., Supelco Co., Bellefonte, PA, USA). The operating parameters were as follows: carrier gas =helium; detector (FID) temperature $=270^{\circ} \mathrm{C}$; injection temperature $=$ $250^{\circ} \mathrm{C}$; column temperature $=180^{\circ} \mathrm{C}$ for $8 \mathrm{~min}$, programmed to increase at $3^{\circ} \mathrm{C} / \mathrm{min}$ up to $230^{\circ} \mathrm{C}$ with a final holding time of 10 
min; split injection at 1:50 ratio. Menhaden oil was used as standard. Each of the specific fatty acid methyl ester peaks was identified by determining its equivalent chain length with reference to the known standard [43].

\subsection{Statistical Analysis}

All statistical analyses were performed using the SPSS 18.0 program and one-way ANOVA test followed by Duncan's multiple range test.

\section{RESULTS AND DISCUSSION}

\subsection{Lipid Content and Compositions}

The total lipid content of dried sea cucumber, A. japonicus, was $4 \pm 1 \%$ ( $\%$ of dry weight). This value was higher than those of Euapta godeffroyi (1.58\%), Holothuria pardalis (1.66\%), Holothuria moebii (2.42\%) and Holothuria impatiens (3.14\%), but lower than those of A. japonicus (3.93\%), Stichopus chloronotus (4.56\%), Holothuria leucospilota (7.16\%) and Abyssocucumis abyssorum (9.00\%) [44, 45]. Lipid composition of dried sea cucumber, A. japonicus, is shown in Table 1. The total lipids consisted of $31 \%$ neutral lipids and $69 \%$ polar lipids which comprised $29 \%$ of glycolipids and $40 \%$ of phospholipids.

It is remarkable that dried sea cucumber, $A$. japonicus, was found to contain significantly higher content of glycolipids compared to $C$. fraudatrix (8.5\%), C. japonica (1.6\%), Haliclona aqueducta (4.3\%), H. panicea (2.8\%) and Myxilla incrustans $(3.2 \%)$ [46, 47].

The phospholipids content of dried sea cucumber was much higher than those of $H$. moebii (12.5\% of total lipids), $H$. impatiens (19.2\%), S. chloronotus $(21.8 \%)$, E. godeffroyi (22.1\%) and $H$. pardalis (26.6\%) [44].

The results of TLC separation of different glycolipids are shown in Fig. (1). The glycolipid compositions of dried sea cucumber, A. japonicus are shown in Table 2 . In this study, MGDG and SG were found as the major glycolipids class. MGDG (37.5\%) was found to be higher than other glycolipids but not significantly different from SG $(33.8 \%)(p<0.05)$. The content of SQDG was $23.6 \%$, which was significantly higher than that of DGDG (2.3\%), 6-O-acyl SG (1.6\%) and of acyl MGDG (1.2\%) and no significant difference was observed in DGDG, 6-O-acyl SG and acyl MGDG $(p<0.05)$. Glycolipids can be found in lower invertebrates such as spongia, echinoderm and zebrafish. Among them, larger amounts of glycolipids have been found in echinoderms like sea cucumbers as they feed on glycolipid-rich algae whereas arthropoda have the lowest glycolipid contents [48].

\subsection{Fatty Acid Compositions}

Although many studies have been conducted about the fatty acid profile in different species of sea cucumbers [20, 49 51], there are a very few studies on lipid class of A. japonicus and there are no studies on the glycolipid fatty acids compositions of sea cucumber, A. japonicus.

Gas chromatography-flame ionization detector chromato- grams of SQDG MGDG and SG are shown in Fig. (2). The fatty acid compositions of MGDG, SG and SQDG in the dried sea cucumber, A. japonicus, are shown in Table 3 . The principal fatty acids of MGDG are as follows: 16:0,18:0, $18: 1 n-9,22: 1 n-9$ and $22: 6 n-3$. Total monounsaturated fatty acids (MUFAs) of total lipids were $23.15 \%$, significantly higher $(p<0.05)$ than Polyunsaturated Fatty Acids (PUFAs) $(18.5 \%)$. The main saturated (SFA) and Polyunsaturated Fatty Acids (PUFA) found in MGDG were palmitic acid (16:0) and docosahexaenoic acid (DHA, 22:6n-3), while the main monounsaturated fatty acids were cis-oleic acid (18:1n-9). There was a low concentrate of arachidonic acid (20:4n-6) and eicosapentaenoic acid (20:5n-3).

Major fatty acids of SG were 14:0, 16:0, 18:0, 18:1n-9, $22: 0,22: 6 n-3$ and $24: 1 n-9$. SG was found to contain significantly higher values of and SFA followed by MUFA, n-9 HUFA PUFA $(p<0.05)$. In this study, the highest amount of n-9 highly monounsaturated fatty acids (HUFA) were found in SG (29\%) compared to MGDG, SQDG. Garg (1998) [52] reported that high-monounsaturated fatty acids could reduce plasma triglycerides by $19 \%$ and "bad" Very-Low-DensityLipoprotein (VLDL) cholesterol by $22 \%$ in patients with diabetes.n-9 highly monounsaturated fatty acids have improved insulin sensitivity and decreased inflammation [53].

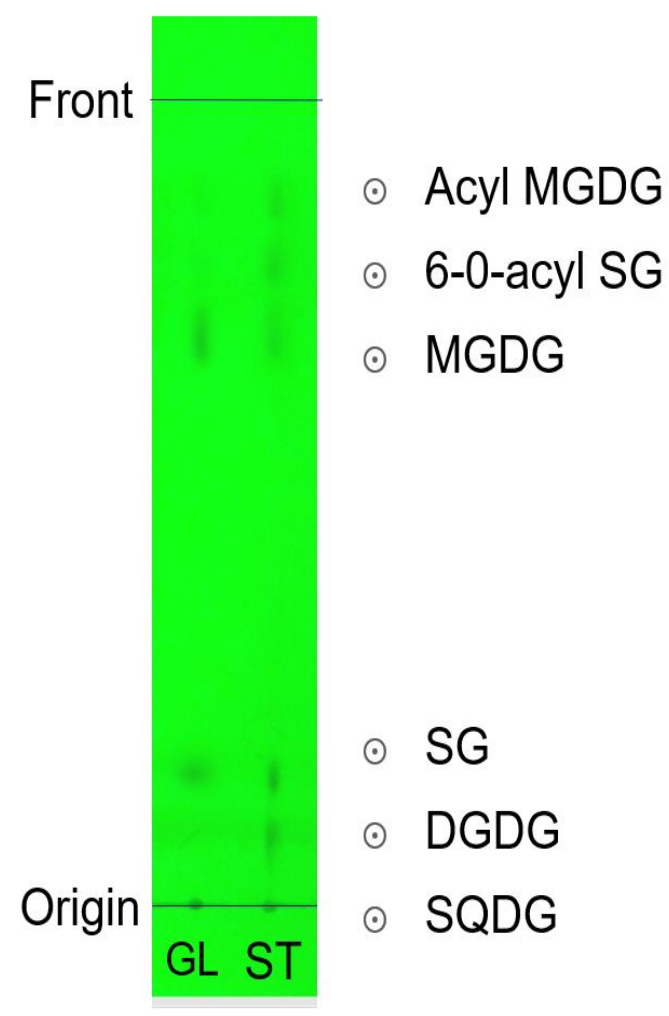

Fig. (1). Schematic TLC separations of glycolipids from dried sea cucumber. Chloroform-acetone-water (30:60:2, v/v/v). acyl monogalactosyl diglycerides (Acyl MGDG), 6-0-acyl steryl glycosides (6-0acyl SG), monogalactosyl diglycerides (MGDG), steryl glycosides (SG), digalactosyl diglycerides (DGDG), and sulfoquinovosyl diglycerides (SQDG). 


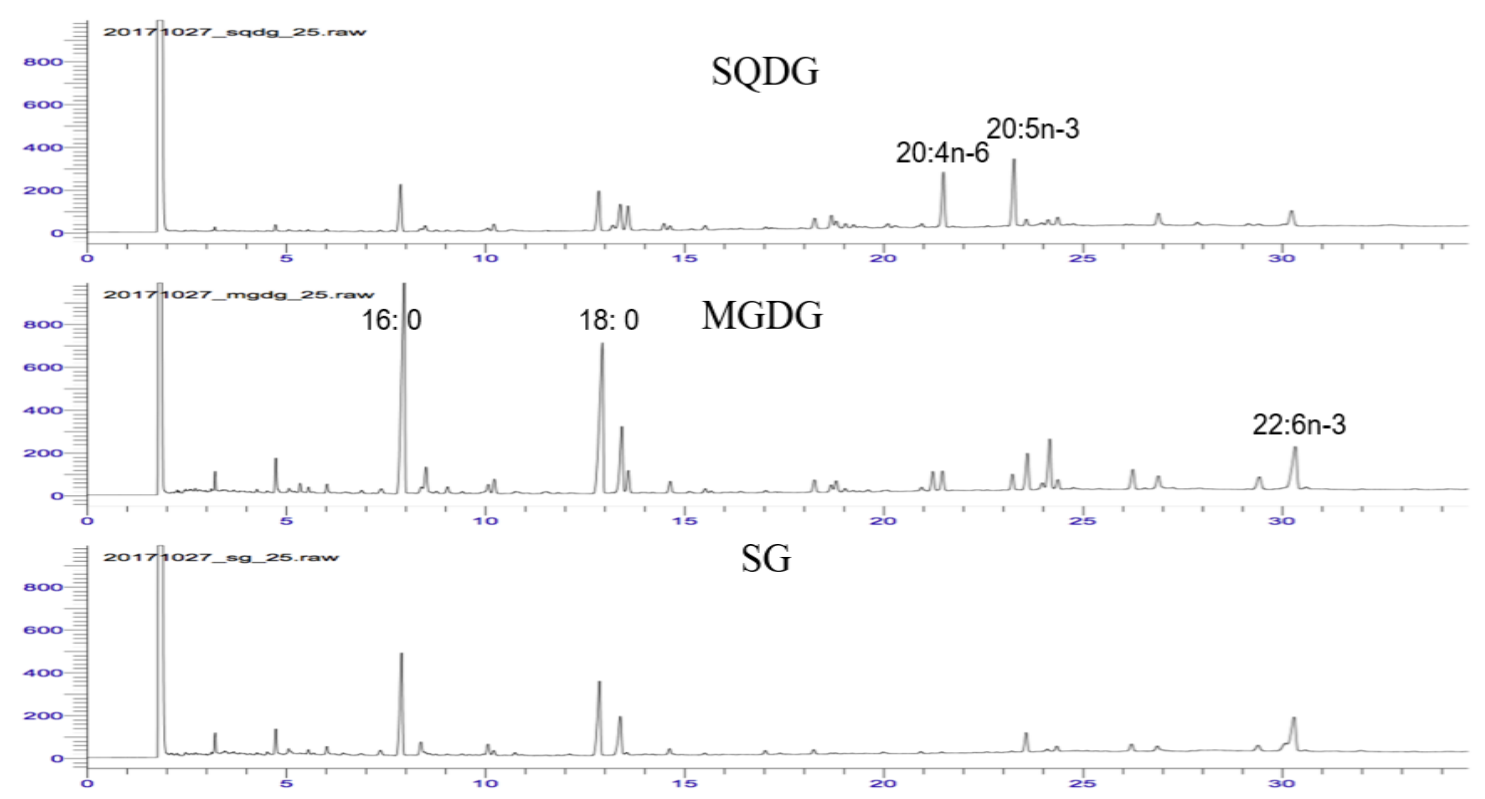

Fig. (2). Gas chromatography-flame ionization detector chromatograms of SQDG, MGDG and SG.

Table 1. Lipid composition of dried sea cucumber, Apostichopus japonicus.

\begin{tabular}{|c|c|}
\hline Lipid Composition & Content (\%) \\
\hline Total lipid & $4 \pm 1^{1}$ \\
\hline Neutral lipids & $31 \pm 1^{2}$ \\
\hline Glycolipids & $29 \pm 1^{2}$ \\
\hline Phospholipids & $40 \pm 1^{2}$ \\
\hline
\end{tabular}

${ }^{1} \%$ of dry weight

${ }^{2} \%$ of total lipids.
Table 2. Glycolipids composition of dried sea cucumber, Apostichopus japonicus.

\begin{tabular}{|c|c|}
\hline Lipid Class & Content (\%) \\
\hline Acly monogalactosyl diglycerides (Acyl MGDG), & $1.2 \pm 0.1^{\mathrm{a}}$ \\
\hline 6-0-acyl steryl glycosides (6-0-acyl SG) & $1.6 \pm 0.2^{\mathrm{a}}$ \\
\hline Monogalactosyl diglycerides (MGDG) & $37.5 \pm 0.3^{\mathrm{d}}$ \\
\hline Steryl glycosides (SG) & $33.8 \pm 0.5^{\mathrm{d}}$ \\
\hline Digalactosyl diglycerides (DGDG) & $2.3 \pm 0.08^{\mathrm{b}}$ \\
\hline Sulfoquinovosyl diglycerides (SQDG) & $23.6 \pm 0.7^{\mathrm{c}}$ \\
\hline
\end{tabular}

Table 3. Fatty acid composition of MGDG, SG and SQDG of dried sea cucumber Apostichopus japonicus.

\begin{tabular}{|c|c|c|c|}
\hline Fatty acids & MGDG & SG & SQDG \\
\hline iso 14:0 & $0.16 \pm 0.02^{\mathrm{b}}$ & $0.56 \pm 0.03^{\mathrm{c}}$ & $0.05 \pm 0.01^{\mathrm{a}}$ \\
\hline $14: 0$ & $1.99 \pm 0.06^{\mathrm{b}}$ & $4.5 \pm 0.6^{\mathrm{c}}$ & $0.24 \pm 0.02^{\mathrm{a}}$ \\
\hline $14: 1 \mathrm{n}-9$ & $0.35 \pm 0.04^{\mathrm{b}}$ & $0.46 \pm 0.02^{\mathrm{c}}$ & $0.11 \pm 0.02^{\mathrm{b}}$ \\
\hline $14: 1 \mathrm{n}-7$ & $0.08 \pm 0.01^{\mathrm{a}}$ & $0.12 \pm 0.01^{\mathrm{b}}$ & $0.18 \pm 0.03^{\mathrm{b}}$ \\
\hline iso 15:0 & $0.53 \pm 0.04^{\mathrm{c}}$ & $0.05 \pm 0.01^{\mathrm{a}}$ & $0.29 \pm 0.02^{\mathrm{a}}$ \\
\hline anteiso-15:0 & $0.34 \pm 0.03^{\mathrm{a}}$ & $0.60 \pm 0.02^{\mathrm{a}}$ & $0.18 \pm 0.02^{\mathrm{a}}$ \\
\hline $15: 0$ & $0.60 \pm 0.05^{\mathrm{b}}$ & $1.3 \pm 0.5^{\mathrm{c}}$ & $0.05 \pm 0.01^{\mathrm{a}}$ \\
\hline $15: 1 \mathrm{n}-8$ & $0.09 \pm 0.02^{\mathrm{a}}$ & $0.07 \pm 0.01^{\mathrm{a}}$ & $0.12 \pm 0.02^{\mathrm{b}}$ \\
\hline $15: 1 \mathrm{n}-5$ & $0.03 \pm 0.01^{\mathrm{a}}$ & $0.05 \pm 0.01^{\mathrm{a}}$ & $\mathrm{ND}^{\mathrm{a}}$ \\
\hline iso 16:0 & $0.29 \pm 0.03^{\mathrm{b}}$ & $0.41 \pm 0.05^{\mathrm{c}}$ & $0.07 \pm 0.01^{\mathrm{a}}$ \\
\hline DMA 16:0 & $\mathrm{ND}$ & $\mathrm{ND}$ & $7.8 \pm 0.7^{\mathrm{a}}$ \\
\hline pristanate & $0.09 \pm 0.01^{\mathrm{a}}$ & $0.10 \pm 0.02^{\mathrm{a}}$ & $\mathrm{ND}^{\mathrm{a}}$ \\
\hline $16: 0$ & $23.9 \pm 0.5^{\mathrm{c}}$ & $20.7 \pm 0.8^{\mathrm{b}}$ & $0.46 \pm 0.02^{\mathrm{a}}$ \\
\hline $16: 1 \mathrm{n}-9$ & $0.53 \pm 0.05^{\mathrm{a}}$ & $2.68 \pm 0.09^{\mathrm{b}}$ & $0.26 \pm 0.03^{\mathrm{b}}$ \\
\hline $16: 1 \mathrm{n}-7$ & $2.12 \pm 0.09^{\mathrm{c}}$ & $0.61 \pm 0.03^{\mathrm{b}}$ & $0.95 \pm 0.07^{\mathrm{a}}$ \\
\hline TME16:0 & $0.17 \pm 0.02^{\mathrm{a}}$ & $0.72 \pm 0.04^{\mathrm{c}}$ & $0.18 \pm 0.02^{\mathrm{a}}$ \\
\hline anteiso 17:0 & $\mathrm{ND}$ & $\mathrm{ND}$ & $0.23 \pm 0.02$ \\
\hline
\end{tabular}




\begin{tabular}{|c|c|c|c|}
\hline Fatty acids & MGDG & SG & SQDG \\
\hline DMA 17:0 & ND & ND & ND \\
\hline $16: 2 n-4$ & $0.96 \pm 0.04^{c}$ & $0.37 \pm 0.03^{\mathrm{a}}$ & $0.80 \pm 0.02^{b}$ \\
\hline $17: 0$ & $1.25 \pm 0.05^{\mathrm{b}}$ & $0.23 \pm 0.02^{\mathrm{a}}$ & $1.24 \pm 0.06^{\mathrm{b}}$ \\
\hline $16: 3 n-4$ & $\mathrm{ND}$ & $0.27 \pm 0.03^{\mathrm{b}}$ & $0.08 \pm 0.01^{\mathrm{a}}$ \\
\hline $16: 3 n-3$ & $0.34 \pm 0.03^{\mathrm{a}}$ & $0.52 \pm 0.04^{\mathrm{b}}$ & $0.55 \pm 0.02^{b}$ \\
\hline $16: 4 n-3$ & $0.44 \pm 0.0^{\mathrm{b}}$ & $0.16 \pm 0.03^{\mathrm{a}}$ & $0.14 \pm 0.03^{\mathrm{a}}$ \\
\hline anteiso 18:0 & ND & ND & $0.21 \pm 0.02^{\mathrm{a}}$ \\
\hline DMA $18: 0$ & $\mathrm{ND}$ & $\mathrm{ND}$ & ND \\
\hline $16: 4 n-1$ & ND & $0.20 \pm 0.04^{\mathrm{a}}$ & $0.21 \pm 0.3^{\mathrm{a}}$ \\
\hline $18: 0$ & $19.04 \pm 0.9^{b}$ & $18.8 \pm 0.8^{\mathrm{b}}$ & $7.2 \pm 0.1^{\mathrm{a}}$ \\
\hline $18: 1 n-9$ & $6.8 \pm 0.5^{\mathrm{a}}$ & $9.1 \pm 0.7^{b}$ & $6.1 \pm 0.5^{\mathrm{a}}$ \\
\hline $18: 1 n-7$ & $1.95 \pm 0.06^{\mathrm{b}}$ & $0.51 \pm 0.04^{\mathrm{a}}$ & $5.5 \pm 0.7^{\mathrm{c}}$ \\
\hline $18: \ln -5$ & ND & ND & $0.26 \pm 0.04^{\mathrm{a}}$ \\
\hline $18: 2 n-6$ & $1.02 \pm 0.02^{\mathrm{a}}$ & $1.04 \pm 0.07^{\mathrm{a}}$ & $1.18 \pm 0.06^{\mathrm{a}}$ \\
\hline DMA 19:0 & ND & ND & ND \\
\hline $18: 2 n-4$ & $0.19 \pm 0.02^{b}$ & $0.05 \pm 0.01^{\mathrm{a}}$ & $0.17 \pm 0.02^{b}$ \\
\hline 19:0 & $0.41 \pm 0.03^{\mathrm{a}}$ & $0.37 \pm 0.03^{\mathrm{a}}$ & $0.83 \pm 0.04^{b}$ \\
\hline $19: 1 n-9$ & ND & $0.06 \pm 0.02^{\mathrm{a}}$ & $0.05 \pm 0.01^{\mathrm{a}}$ \\
\hline $18: 3 n-3$ & $0.04 \pm 0.01^{\mathrm{a}}$ & $0.07 \pm 0.01^{\mathrm{a}}$ & $0.18 \pm 0.02^{b}$ \\
\hline DMA 20:0 & ND & ND & ND \\
\hline $20: 0$ & $1.17 \pm 0.04^{b}$ & $0.92 \pm 0.03^{\mathrm{a}}$ & $1.98 \pm 0.03^{\mathrm{c}}$ \\
\hline $20: 1 n-11$ & $0.96 \pm 0.08^{\mathrm{a}}$ & ND & $2.39 \pm 0.06^{b}$ \\
\hline $20: 1 n-9$ & $1.09 \pm 0.03^{b}$ & $0.18 \pm 0.02^{\mathrm{a}}$ & $1.36 \pm 0.06^{\mathrm{c}}$ \\
\hline $20: 1 n-7$ & $0.30 \pm 0.05^{\mathrm{b}}$ & $0.17 \pm 0.02^{\mathrm{a}}$ & $0.80 \pm 0.05^{\mathrm{c}}$ \\
\hline $20: 1 n-5$ & $0.11 \pm 0.02^{\mathrm{a}}$ & $0.09 \pm 0.01^{\mathrm{a}}$ & $0.58 \pm 0.03^{b}$ \\
\hline $20:: 1$ NMID & ND & $0.08 \pm 0.01^{\mathrm{a}}$ & $0.24 \pm 0.02^{b}$ \\
\hline $20: 2 n-6$ & ND & $0.37 \pm 0.02^{\mathrm{a}}$ & $0.87 \pm 0.05^{b}$ \\
\hline 20:3NMIT & $\mathrm{ND}$ & $0.06 \pm 0.01^{\mathrm{a}}$ & $0.40 \pm 0.03^{\mathrm{b}}$ \\
\hline $20: 3 n-6$ & $0.37 \pm 0.03^{b}$ & $0.44 \pm 0.03^{\mathrm{b}}$ & $0.23 \pm 0.02^{\mathrm{a}}$ \\
\hline $21: 0$ & $1.84 \pm 0.06^{\mathrm{c}}$ & $0.37 \pm 0.02^{\mathrm{a}}$ & $0.67 \pm 0.06^{\mathrm{b}}$ \\
\hline $20: 4 n-6$ & $1.91 \pm 0.07^{\mathrm{b}}$ & $0.20 \pm 0.02^{\mathrm{a}}$ & $18.3 \pm 1^{\mathrm{c}}$ \\
\hline $21: 1 n-9$ & ND & $0.15 \pm 0.02^{a}$ & $0.23 \pm 0.02^{b}$ \\
\hline $21: 1 n-7$ & ND & $1.15 \pm 0.06^{\mathrm{b}}$ & $0.11 \pm 0.01^{\mathrm{a}}$ \\
\hline $20: 4 n-3$ & $1.91 \pm 0.07^{\mathrm{b}}$ & $0.28 \pm 0.03^{\mathrm{a}}$ & ND \\
\hline $20: 5 n-3$ & $1.44 \pm 0.08^{b}$ & $0.06 \pm 0.01^{\mathrm{a}}$ & $20.3 \pm 1^{\mathrm{c}}$ \\
\hline $22: 0$ & $3.69 \pm 0.09^{b}$ & $5.03 \pm 0.14^{\mathrm{c}}$ & $1.11 \pm 0.03^{\mathrm{a}}$ \\
\hline $22: 1 n-11$ & $0.63 \pm 0.03^{\mathrm{a}}$ & $\mathrm{ND}$ & $0.73 \pm 0.06^{\mathrm{a}}$ \\
\hline $22: 1 n-9$ & $5.2 \pm 0.2^{\mathrm{c}}$ & $0.52 \pm 0.06^{\mathrm{a}}$ & $1.14 \pm 0.05^{b}$ \\
\hline $22: 1 n-7$ & $0.94 \pm 0.07^{\mathrm{a}}$ & $1.2 \pm 0.1^{\mathrm{b}}$ & $1.50 \pm 0.07^{\mathrm{c}}$ \\
\hline $22: 1 n-5$ & $0.11 \pm 0.02^{\mathrm{a}}$ & $0.12 \pm 0.03^{\mathrm{a}}$ & $0.13 \pm 0.03^{\mathrm{a}}$ \\
\hline $22: 2 n-6$ & $0.23 \pm 0.03^{\mathrm{a}}$ & $\mathrm{ND}$ & $0.30 \pm 0.03^{\mathrm{a}}$ \\
\hline $22: 3 n-6$ & ND & ND & $0.19 \pm 0.02^{\mathrm{a}}$ \\
\hline $23: 0$ & $2.19 \pm 0.08^{\mathrm{c}}$ & $1.73 \pm 0.04^{\mathrm{b}}$ & $0.18 \pm 0.03^{\mathrm{a}}$ \\
\hline $23: 1 n-9$ & $1.65 \pm 0.07^{\mathrm{a}}$ & $1.58 \pm 0.03^{\mathrm{a}}$ & $2.86 \pm 0.07^{\mathrm{b}}$ \\
\hline $23: 1 n-7$ & ND & ND & $0.10 \pm 0.02^{\mathrm{a}}$ \\
\hline $22: 5 n-6$ & ND & $\mathrm{ND}$ & $0.12 \pm 0.01^{\mathrm{a}}$ \\
\hline $23: 5 n-3$ & ND & ND & ND \\
\hline $23: 5 n-3$ & $1.83 \pm 0.09^{c}$ & $0.35 \pm 0.03^{\mathrm{a}}$ & $0.51 \pm 0.03^{b}$ \\
\hline $24: 0$ & $\mathrm{ND}$ & $1.74 \pm 0.07^{\mathrm{b}}$ & $0.42 \pm 0.05^{\mathrm{a}}$ \\
\hline $22: 6 n-3$ & $7.8 \pm 0.2^{c}$ & $3.54 \pm 0.09^{\mathrm{b}}$ & $2.21 \pm 0.08^{a}$ \\
\hline $24: \ln -9$ & $0.25 \pm 0.02^{\mathrm{a}}$ & $14.21 \pm 0.4^{\mathrm{c}}$ & $3.4 \pm 0.11^{\mathrm{b}}$ \\
\hline
\end{tabular}


(Table 3) contd.....

\begin{tabular}{|c|c|c|c|}
\hline Fatty acids & MGDG & SG & SQDG \\
\hline$\sum$ n-9 HUFA & $16 \pm 1^{\mathrm{a}}$ & $29 \pm 1^{b}$ & $15 \pm 1^{\mathrm{a}}$ \\
\hline$\sum \mathrm{BCFA}$ & $1.58 \pm 0.08^{\mathrm{a}}$ & $2.81 \pm 0.07^{\mathrm{c}}$ & $2.11 \pm 0.04^{b}$ \\
\hline$\sum \mathrm{SFA}$ & $56 \pm 2^{b}$ & $56 \pm 2^{b}$ & $22 \pm 1^{\mathrm{a}}$ \\
\hline$\sum$ MUFA & $23.15 \pm 1.35^{\mathrm{a}}$ & $33 \pm 1^{\mathrm{c}}$ & $29 \pm 1^{\mathrm{b}}$ \\
\hline$\sum$ PUFA & $18.5 \pm 2^{b}$ & $7.7 \pm 0.9^{\mathrm{a}}$ & $46.1 \pm 2^{\mathrm{c}}$ \\
\hline
\end{tabular}

Different superscript letters indicate a statistically significant difference $(\mathrm{P}<0.05)$. ND, not detected; HUFA, Highly monounsaturated fatty acids; BCFA, Branched-chain fatty acid; SFA, Saturated fatty acid; MUFA, Monounsaturated fatty acid; PUFA, Polyunsaturated fatty acid; NMID, non-methylene interrupted dienoic fatty acid; NMIT, nonmethylene interrupted trienoic fatty acid.

Fatty acids present in the SQDG at $5 \%$ or more of the total fatty acids were $16: 0,18: 0,18: 1 n-7,18: 1 n-9,20: 4 n-6$ and 20:5n-3. SQDG contained significantly higher 20:4n-6 (arachidonic acid) and eicosapentaenoic acid (EPA, 20:5n-3), but lower oleic acid (18:1n-9) and docosahexaenoic acid (DHA, 22:6n-3), compared with those of MGDG and SG ( $p<$ $0.05)$. Moreover, among the PUFAs of sea cucumber, the level of EPA was higher than AA which was similar to the temperate Euapta fraudatrix, but the tropical $H$. leucospilota was just the opposite [44]. Arachidonic acid promotes the tissue repair, growth of skeletal muscle tissue and early neurological development [54]. Jais et al. (1992) [55] also reported that arachidonic acid plays an important role in blood clotting, thus providing wound healing properties. The high content of EPA and AA of sea cucumber may be associated with their selfrepair ability.

In this study, a considerable amount of branched chain fatty acids (BCFA) was found in MGDG, SG and SQDG. It is well-known that Sea-bed sediments contain a high level of branched-chain fatty acids which are derived from microorganisms $[56,57]$. The detritus is the major diet of the holothurians like sea cucumbers and branched fatty acids, which were detected in this study, are derived from this diet. BCFA play a vital role to increase the expression of antiinflammatory cytokine IL-10 and protect against necrotizing enterocolitis (NEC) in the rat pup model [58].

Polyunsaturated fatty acids (PUFAs) found in MGDG, SG and SQDG were 18.5, 7.7 and 46.1\%, respectively. Long-chain polyunsaturated fatty acids especially arachidonic acid (AA, 20:4n-6), eicosapentaenoic acid (EPA, 20:5n-3) and docosahexaenoic acid (DHA, 22:6n-3) can reduce inflammation, cancer, and arthritis [59]. According to Jingjing Li et al. [60], intakes of longchain n-3 PUFAs are inversely co-related with the incidence of an inflammatory disease like asthma in American young adults.

\section{CONCLUSION}

As a result of this study, total lipids were relatively rich in dried sea cucumber, A. japonicus, and contained considerable content of BCFA, MUFA, PUFAs and n-9 HUFA. Moreover, some differences were observed in the fatty acid compositions among MGDG, SG and SQDG. Further investigation is required to understand the positional distribution of fatty acids and molecular species in MGDG, SG and SQDG in detail.

\section{ETHICS APPROVAL AND CONSENT TO PARTICIPATE}

All experimental protocols were approved by Institutional Animal Care and Use Committee (IACUC) of the Gyeongsang National University, Republic of Korea.

\section{HUMAN AND ANIMAL RIGHTS}

No humans were used in the study. All experiments on animals were followed according to guidelines of the Institutional Animal Care and Use Committee (IACUC) of the Gyeongsang National University, Republic of Korea.

\section{CONSENT FOR PUBLICATION}

Not applicable.

\section{AVAILABILITY OF DATA AND MATERIALS}

All datasets generated during and/or analyzed during the current study are available from the corresponding author on reasonable request.

\section{FUNDING}

This study was supported by "Development of 10 HP Hybrid (Decompression Type-Heat Pump System) Dryer for Drying of Marine Products (Sea Cucumber, Oyster)" from the Korea Institute of Energy Technology Evaluation and Planning (KETEP) and the Ministry of Trade, Industry \& Energy (MOTIE) of the Republic of Korea (Grant No. 10067058).

\section{CONFLICT OF INTEREST}

The authors declare no conflict of interest, financial or otherwise.

\section{ACKNOWLEDGEMENTS}

Declared none.

\section{REFERENCES}

[1] Mcelroy S. Beche-de-mer species of commercial value-An update. SPC Beche-de-mer Inf Bull 1990; 2: 2-7.

[2] Lovatelli A, Conand C, Purcell S, Uthicke S, Hamel J, Mercier A. Advances in Sea cucumber aquaculture and Management FAO Fisheries technical paper. Italy: FAO Rome 2004; pp. 425-63.

[3] Conand C. Present status of world sea cucumber resources and utilization: An international overview.Advances in Sea cucumber aquaculture and Management. Rome, Italy: FAO 2004; pp. 13-23.

[4] Yuan X, Yang H, Zhou Y, Mao T, Zhang T, Liu Y. The influence of diets containing dried bivalve feces and/or powdered algae on growth and energy distribution in sea cucumber Apostichopus japonicus (Selenka) (Echinodermata: Holothuroidea). Aquacult 2006; 256: 457-67.

[http://dx.doi.org/10.1016/j.aquaculture.2006.01.029]

[5] Kamrunnahar K, Anisuzzaman M, Jeong UC, Da-In L, Hak-Sun Y, Seok-Joong K. Effects of Diets Containing different concentration of Saccharina japonica Algae on Growth and Interleukin (IL)-10 Gene Expression of Juvenile Sea cucumber Apostichopus japonicus. Annu Res Rev Biol 2018; 29(2): 1-11. [http://dx.doi.org/10.9734/ARRB/2018/44013]

[6] Robinson G, Lovetelli A. Global sea cucumber fisheries and aquaculture FAO's inputs over the past few years. FAO Aquaculture Newsletter 2015; 53: 55-7. [https://www.researchgate.net/publication/ $276328588]$. 
[7] Yingst JY. The utilization of organic matter in shallow marine sediments by an epibenthic deposit-feeding holothurian. J Exp Mar Biol Ecol 1976; 23: 55-69.

[http://dx.doi.org/10.1016/0022-0981(76)90085-X]

[8] Moriarty DJW. Feeding of Holothuria atra and Stichopus chloronotus on bacteria, organic carbon and organic nitrogen in sediments of the Great Barrier Reef. Aust J Mar Freshwater Res 1982; 33: 255-63. [http://dx.doi.org/10.1071/MF9820255].

[http://dx.doi.org/10.1071/MF9820255]

[9] Zhang BL, Sun DL, Wu YQ. Preliminary analysis on the feeding habit of Apostichopus japonicus in the rocky coast waters off Lingshan Island. Mark Sci 1995; 3: 11-3.

[10] Feng J, Jong-Kuk C. U-Cheol Jeong, Anisuzzaman M, Chung-Ho R, Byeong-Dae C, Seok-Joong K. Effects of fermented fecal solid diets on growth of the sea cucumber Apostichopus japonicus. Korean J Fish Aqua Sci 2016; 49: 161-7.

[11] Anisuzzaman M. U-Cheol Jeong, Feng J, Jong-Kuk C, Kamrunnahar K, Da-In L, Hak-Sun Y, Seok-Joong K. Effects of different algae in diet on growth and interleukin (IL)-10 production of juvenile sea cucumber Apostichopus japonicus. Fish \& Aqua Sci 2017; 20: 1-8. [http://dx.doi.org/10.1186/s41240-017-0069-5].

[12] Anisuzzaman M, Feng J. U-Cheol Jeong, Jong-Kuk C, Hak-Sun Y, Da-In L, Seok-Joong K. Effects of Nannochloropsis concentration in diet on growth, survival and anti-inflammatory cytokine (Interleukin-10) production of the sea cucumber Apostichopus japonicus. Turk J Fish Aquat Sci 2018; 18: 567-75. [http://dx.doi.org/ 10.4194/1303-2712-v18_4_08].

[13] Conand C. The fishery resources of pacific island countries. Part 2: Holothurians, FAO Fisheries Technical Paper 1990.http: //www.fao.org/docrep/008/t0293e/t0293e00.-html Retrieved from FAO website.

[14] Duan X, Zhang M, Mujumdar AS, Wang SJ. Microwave freeze drying of sea cucumber Stichopus japonicus. J Food Eng 2010; 96: 491-7. [http://dx.doi.org/10.1016/j.jfoodeng.2009.08.031]

[15] Chang-Lee MV, Price RJ, Lampila LE. Effect of processing on proximate composition and mineral content of sea cucumbers (Parastichopus spp.). J Food Sci 1989; 54: 567-72. [http://dx.doi.org/10.1111/j.1365-2621.1989.tb04653.x]

[16] A-1 Fish, Crustaceans, Molluscs, etc, Fisheries Statistics 2007. Rome 2009; p. 27.

[17] Ferdouse F. World markets and trade flows of sea cucumber/bechede-mer.Advances in Sea Cucumber Aquaculture and Management. Rome: FAO 2004; pp. 101-18.

[18] Cakli Ş, Cadun A, Kişla D, Dincer T. Determination of quality characteristics of Holothuria tubulosa,(Gmelin, 1788) in Turkish sea (Aegean Region) depending on sun drying process step used in Turkey. J Aquat Food Prod Technol 2004; 13(3): 69-78. [https://doi.org/10.1300/J030v13n03_07]. [http://dx.doi.org/10.1300/J030v13n03 07]

[19] Chen J. Present status and prospects of sea cucumber industry in China. FAO Fish Tech Pap 2005; 1: 25-38.

[20] Fredalina BD, Ridzwan BH, Abidin AA, et al. Fatty acid compositions in local sea cucumber, Stichopus chloronotus, for wound healing. Gen Pharmacol 1999; 33(4): 337-40. [https://doi.org/10.1016/S03063623(98)00253-5]

[http://dx.doi.org/10.1016/S0306-3623(98)00253-5] [PMID: 10523 072]

[21] Bordbar S, Anwar F, Saari N. High-value components and bioactives from sea cucumbers for functional foods--a review. Mar Drugs 2011; 9(10): 1761-805

[http://dx.doi.org/10.3390/md9101761] [PMID: 22072996]

[22] Guo Y, Ding Y, Xu F, et al. Systems pharmacology-based drug discovery for marine resources: an example using sea cucumber (Holothurians). J Ethnopharmacol 2015; 165: 61-72.

[http://dx.doi.org/10.1016/j.jep.2015.02.029] [PMID: 25701746]

[23] Feng J, Anisuzzaman M. U-Cheol Jeong, Jong-Kuk C, Hak-Sun Y, Seung-Wan K, Seok-Joong K. Comparison of Fatty Acid Composition of Wild and Cultured Sea Cucumber Apostichopus japonicus. Korean J Fish Aqua Sci 2016; 49: 474-85. [http://dx.doi.org/10.5657/ KFAS.2016.0474]

[24] Vergara W, Rodríguez A. Nutritional composition of sea cucumber Isostichopus sp. Nat Resour 2016; 7(03): 130. [https://doi. org/10.4236/nr.2016.73013].

[http://dx.doi.org/10.4236/nr.2016.73013]

[25] Anisuzzaman M. U-Cheol Jeong, Feng J, Kamrunnahar K, Jong-Kuk C, Da-In L, Hak-Sun Y, Seok-Joong K. Effects of Ulva lactuca and Laminaria japonica algae in prepared feeds on growth, survival, fatty acid compositions and Interleukin (IL)-10 production of sea cucumber Apostichopus japonicus. Int J Fish \& Aqua Stu 2018; 6(2): 387-95.

[26] Esmat AY, Said MM, Soliman AA, El-Masry KS, Badiea EA Bioactive compounds, antioxidant potential, and hepatoprotective activity of sea cucumber (Holothuria atra) against thioacetamide intoxication in rats. Nutrition 2013; 29(1): 258-67. [https://doi. org/10.1016/j.nut.2012.06.004].

[http://dx.doi.org/10.1016/j.nut.2012.06.004] [PMID: 23085016]

[27] Farshadpour F, Gharibi S, Taherzadeh M, et al. Antiviral activity of Holothuria sp. a sea cucumber against herpes simplex virus type 1 (HSV-1). Eur Rev Med Pharmacol Sci 2014; 18(3): 333-7.

[PMID: 24563431]

[28] Kiani N, Heidari B, Rassa M, Kadkhodazadeh M, Heidari B. Antibacterial activity of the body wall extracts of sea cucumber (Invertebrata; Echinodermata) on infectious oral streptococci. J Basic Clin Physiol Pharmacol 2014; 1: 1-7. [https://doi.org/10.1515/jbcpp2013-0010].

[http://dx.doi.org/10.1515/jbcpp-2013-0010] [PMID: 24468613]

[29] Wijesinghe WA, Jeon YJ, Ramasamy P, Wahid ME, Vairappan CS. Anticancer activity and mediation of apoptosis in human HL-60 leukaemia cells by edible sea cucumber (Holothuria edulis) extract. Food Chem 2013; 139(1-4): 326-31. [https://doi.org/10.1016/j. foodchem.2013.01.058].

[http://dx.doi.org/10.1016/j.foodchem.2013.01.058] [PMID: 235611 13]

[30] Lee DI, Kang SA, Md A, et al. Sea Cucumber Lipid-Soluble Extra Fraction Prevents Ovalbumin-Induced Allergic Airway Inflammation. J Med Food 2018; 21(1): 21-9.

[http://dx.doi.org/10.1089/jmf.2017.3994] [PMID: 29161525]

[31] Sargent JR, Tocher DR, Bell JG. The lipids. In: Halver JE, Hardy RW, Eds. Fish Nutrition, 3rd ed. San Diego, California: Elsevier (Academic Press) 2002; pp. 181-257.

[32] Tocher DR. Metabolism and functions of lipids and fatty acids in teleost fish. Rev Fish Sci 2003; 11: 107-84.

[http://dx.doi.org/10.1080/713610925]

[33] Harper CR, Jacobson TA. Usefulness of omega-3 fatty acids and the prevention of coronary heart disease. Am J Cardiol 2005; 96(11): 1521-9.

[http://dx.doi.org/10.1016/j.amjcard.2005.07.071] [PMID: 16310434]

[34] Roynette CE, Calder PC, Dupertuis YM, Pichard C. n-3 polyunsaturated fatty acids and colon cancer prevention. Clin Nutr 2004; 23(2): 139-51.

[http://dx.doi.org/10.1016/j.clnu.2003.07.005] [PMID: 15030953]

[35] Jais AMM, McCulloch R, Croft K. Fatty acid and amino acid composition in haruan as a potential role in wound healing. Gen Pharmacol 1994; 25(5): 947-50.

[http://dx.doi.org/10.1016/0306-3623(94)90101-5] [PMID: 7835642]

[36] Fu XY, Xue CH, Miao BC, Li ZJ, Gao X, Yang WG. Characterization of proteases from the digestive tract of sea cucumber (Stichopus japonicus):High alkaline protease activity. Aquacult 2005; 246: 321-9. [http://dx.doi.org/10.1016/j.aquaculture.2005.01.012]

[37] Wang Y, Wang JF, Gao S, et al. Protective effect of collagen polypeptides from Apostichopus japonicus on the skin of photoagingmodel mice induced by ultraviolet irradiation. Zhongguo Yaoke Daxue Xuebao 2007; 39: 64-7.

[38] Fan TJ, Yuan WP, Cong RS, Yang XX, Wang WW, Jing Z. [Studies on the purification of water-soluble holothurian glycosides from Apostichopus japonicus and their tumor suppressing activity]. Yao Xue Xue Bao 2009; 44(1): 25-31. [PMID: 19350817]

[39] Li C, Li H, Guo S, Li X, Zhu X. Evaluation of processing methods on the nutritional quality of sea cucumber (Apostichopus japonicus Selenka). J Aquat Food Prod Technol 2018; 27(4): 406-17. [https://doi.org/10.1080/10498850.2013.803271]. [http://dx.doi.org/10.1080/10498850.2013.803271]

[40] Bligh EG, Dyer WJ. A rapid method of total lipid extraction and purification. Can J Biochem Physiol 1959; 37(8): 911-7. [http://dx.doi.org/10.1139/o59-099] [PMID: 13671378]

[41] Néron S, El Amrani F, Potus J, Nicolas J. Separation and quantification by high-performance liquid chromatography with light scattering detection of the main wheat flour phospholipids during dough mixing in the presence of phospholipase. J Chromatogr A 2004; 1047(1): 77-83.

[http://dx.doi.org/10.1016/j.chroma.2004.06.105] [PMID: 15481462]

[42] Pongmuangmul S, Phumiamorn S, Sanguansermsri P, Wongkattiya N, Fraser IH, Sanguansermsri D. Anti-herpes simplex virus activities of monogalactosyl diglyceride and digalactosyl diglyceride from 
Clinacanthus nutans, a traditional Thai herbal medicine. Asian Pac J Trop Biomed 2016; 6(3): 192-7.

[http://dx.doi.org/10.1016/j.apjtb.2015.12.014]

[43] Ackman RG. Temperature effects in the calculation of equivalent chain length values for multiple-branched fatty acid esters and ketones on polar and non-polar open tubular columns. J Chromatogr A 1969; 42: $170-5$.

[http://dx.doi.org/10.1016/S0021-9673(01)80612-9]

[44] Svetashev VI, Levin VS, Lam CN. Lipid and fatty acid composition of Holothurians from tropical and temperate waters. Comp Biochem Physiol B 1991; 98: 489-94.

[http://dx.doi.org/10.1016/0305-0491(91)90242-6]

[45] Drazen JC, Phleger CF, Guest MA, Nichols PD. Lipid, sterols and fatty acid composition of abyssal holothurians and ophiuroids from the North-East Pacific Ocean: food web implications. Comp Biochem Physiol B Biochem Mol Biol 2008; 151(1): 79-87.

[http://dx.doi.org/10.1016/j.cbpb.2008.05.013] [PMID: 18577461]

[46] Joseph JD. Lipid composition of marine and estuarine invertebrates: porifera and cnidaria. Prog Lipid Res 1979; 18(1): 1-30. [http://dx.doi.org/10.1016/0163-7827(79)90002-X] [PMID: 42926]

[47] Gilles B. Glycolipids from Marine Invertebrates. Wiley-vch verlag gmbh co kgaa 2014; 1: 99-161.

[48] Vaskovsky VE, Kostetsky EY, Svetaschev VI, Zhukova IG, Smirnova GP. Glycolipids of marine invertebrates. Com biochem physiol 1970; 34: $163-77$.

[http://dx.doi.org/10.1016/0010-406X(70)90064-2]

[49] Ginger ML, Santos VL, Wolff GA. A preliminary investigation of the lipids of abyssal holothurians from the north east Atlantic Ocean. J Mar Biol Assoc U K 2000; 80(1): 139-46. [https://doi.org/10.1017/ s0025315499001654].

[http://dx.doi.org/10.1017/S0025315499001654]

[50] Haider MS, Sultana R, Jamil K, Tarar OM, Afzal W. A study on proximate composition, amino acid profile, fatty acid profile and some mineral contents in two species of sea cucumber. J Anim Plant Sci 2015; 25(1): 168-75.

[51] Wen J, Hu C, Fan S. Chemical composition and nutritional quality of sea cucumbers. J Sci Food Agric 2010; 90(14): 2469-74. [https://doi.org/10.1002/jsfa.4108]. [http://dx.doi.org/10.1002/jsfa.4108] [PMID: 20718029]
[52] Garg A. High-monounsaturated-fat diets for patients with diabetes mellitus: a meta-analysis. Am J Clin Nutr 1998; 67(3)(Suppl.): 577S-82S. [https://doi. org/10.1093/ajcn/67.3.577S].

[http://dx.doi.org/10.1093/ajen/67.3.577S] [PMID: 9497173]

[53] Finucane OM, Lyons CL, Murphy AM, et al. Monounsaturated fatty acid-enriched high-fat diets impede adipose NLRP3 inflammasomemediated IL-1 $\beta$ secretion and insulin resistance despite obesity. Diabetes 2015; 64(6): 2116-28. [https://doi. org/10.2337/db14-1098]. [http://dx.doi.org/10.2337/db14-1098] [PMID: 25626736]

[54] Trappe TA, Liu SZ. Effects of prostaglandins and COX-inhibiting drugs on skeletal muscle adaptations to exercise. J Appl Physiol 2013, 115(6): 909-19. [https://doi. org/10.1152/japplphysiol.00061.2013. PMC 3764617].

[http://dx.doi.org/10.1152/japplphysiol.00061.2013] [PMID: 23539 318]

[55] Jais AMM, McCulloch R, Croft K. Fatty acid and amino acid composition in haruan as a potential role in wound healing. Gen Pharmacol 1994; 25(5): 947-50

[http://dx.doi.org/10.1016/0306-3623(94)90101-5] [PMID: 7835642]

[56] Leo RF, Parker PL. Branched-chain Fatty acids in sediments. Science 1966; 152(3722): 649-50.

[http://dx.doi.org/10.1126/science.152.3722.649] [PMID: 17779505]

[57] Sargent JR, Hopkins CC, Sciring JV, Youngson A. Partial characterization of organic material in surface sediments from Balsorden, Northern Norway, in relation to its origin and nutritional value for sediment ingesting animals. Mar Biol 1983; 76: 85-94. [http://dx.doi.org/10.1007/BF00393059]

[58] Ran-Ressler RR, Glahn RP, Bae S, Brenna JT. Branched-chain fatty acids in the neonatal gut and estimated dietary intake in infancy and adulthood. Nestle Nutr Inst Workshop Ser 2013; 77: 133-43. [http://dx.doi.org/10.1159/000351396] [PMID: 24107503]

[59] Harper CR, Jacobson TA. Usefulness of omega-3 fatty acids and the prevention of coronary heart disease. Am J Cardiol 2005; 96(11): 1521-9.

[http://dx.doi.org/10.1016/j.amjcard.2005.07.071] [PMID: 16310434]

[60] Li J, Xun P, Zamora D, et al. Intakes of long-chain omega-3 (n-3) PUFAs and fish in relation to incidence of asthma among American young adults: the CARDIA study. Am J Clin Nutr 2013; 97(1): 173-8. [http://dx.doi.org/10.3945/ajen.112.041145] [PMID: 23193002]

\section{C) 2019 Anisuzzaman et al.}

This is an open access article distributed under the terms of the Creative Commons Attribution 4.0 International Public License (CC-BY 4.0), a copy of which is available at: https://creativecommons.org/licenses/by/4.0/legalcode. This license permits unrestricted use, distribution, and reproduction in any medium, provided the original author and source are credited. 